УДК 378.147.227+378.096:[378.6]+378.14.015.62

DOI 10.11603/2414-4533.2019.1.9921

В. М. МАЦЬКЕВИЧ, Д. Б. СОЛОМЧАК

ДВНЗ “Івано-Франківський національний медичний університет”

\title{
Селекція отриманої студентами медичного факультету наукової інформації для окреслення смислового поля основних поданих позицій
}

\begin{abstract}
Мета роботы: визначення вправності пошуку літературних джерел із вибором відомостей, які мають оптимальну доказову базу, та здатності до виокремлення квінтесенції наукового повідомлення з подальшим розвитком аналітичного мислення у студентів факультетів природничих наук.

Матеріали і методи. Протягом 2016-2018 рр. у дослідженні брали участь 80 студентів медичного факультету, яким було дано тему для пошуку та опрацювання з встановленням найінформативніших матеріалів у межах встановленого часу, визначення семантичного поля статі, критичної оцінки тексту та написанні власного рейтингу опрацьованих статей згідно з наявною доказовою базою. Вивчено кількість опрацьованих статей респондентами, витрату продуктивного часу на матеріал, який опосередковано належить до пошукового запиту, правильність вибору квінтесенції текстів, визначення компонентів емпіричного циклу наукових досліджень.

Результати досліджень та їх обговорення. Протягом відведеного часу 42,5 \% анкетованих осіб опрацювали 10 і більше статей, 51,25 \% - від 5 до 9 статей, 6,25 \% - від 1 до 4 статей. Щодо заданих ключових слів у пошукових запитах, то 7,5 \% студентів відвели близько третини часу на розгляд інформації, яка не була пов'язана 3 конкретним запитанням. 3 правильним вибором квінтесенції текстів справились 57 студентів (71,25 \%). Визначили компоненти емпіричного циклу 24 особи (30 \%).
\end{abstract}

Ключові слова: емпіричний цикл; пошуковий запит; семантичне поле.

Для професійного росту студентам природничих наук необхідний постійний моніторинг нової літератури, зокрема англійською мовою. Семантика германської групи мов кардинально відрізняється від лінгвістичних особливостей мов східнослов'янської підгрупи. Незважаючи на складність, спілкування англійською мовою за стандартом Західного кодексу частіше стає нормою для поширення інформації, іï обміну та дискусії в наукових колах [1]. Професор Оксфордського університету Т. Грінхальх у п'ятій редакції своєї монографії підкреслює неспадаючий інтерес студентів медичних факультетів до алгоритму читання робіт на основі доказової медицини. Вона наголошує на проблемі розуміння текстів студентами, внаслідок складного їх написання [2]. Студентам, для яких англійська мова $€$ іноземною, необхідно затратити більше часу як на опрацювання смислового навантаження тексту, так і граматичних нюансів, сталих фраз та ідіом.

Мета роботи: визначення вправності пошуку літературних джерел із вибором відомостей, які носять оптимальну доказову базу та здатності виокремлення квінтесенції наукового повідомлення з подальшим розвитком аналітичного мислення у студентів факультетів природничих наук.

У 2016-2018 рр. 80 студентів четвертого та п'ятого курсів медичного факультету з українською мовою навчання було залучено до дослідження. Від усіх учасників отримано інформовану згоду щодо обробки даних на підставі конфіденційних умов. Респондентам дано тему для оглядового пошуку відповідних доступних джерел протягом трьох годин. Умовою було використання тільки англомовної літератури. Завдання всіх осіб полягали у правильному формулюванні пошукового запиту для отримання найбільш інформативних відповідних матеріалів у межах встановленого часу, визначення семантичного поля статті, критичної оцінки тексту та написанні власного рейтингу опрацьованих статей згідно з наявностю доказовою базою.

Протягом відведеного часу 42,5 \% анкетованих осіб опрацювали 10 і більше статей, 51,25 \% від 5 до 9 статей, 6,25 \% - від 1 до 4 статей. Щодо заданих ключових слів у пошукових запитах, то для прикладу у завданні “Передумови та попередження виникнення контраст-індукованої нефропатії” 7,5 \% студентів відвели близько третини часу на розгляд різних видів нефропатій (при вагітності, діабетична, спадкова), детально опрацьовуючи інформацію, яка не була пов'язана з конкретним запитанням. Відповідно, що оцінювання доказової бази статей по контраст-індукованій нефропатії у вищевказаних осіб було проведено поверхнево, через брак часу.

3 правильним вибором квінтесенції обраних текстів справились 57 студентів (71,25 \%). Неправильне розуміння суті статей полягало у зосередженні студентів на актуальності теми та нехтування статистичними показниками, які, як відомо, є “ядром” кожної наукової роботи, яка грунтується на доказових принципах.

3 пропозицією визначити компоненти емпіричного циклу в обраних статтях вправно впора- 
лись 24 особи (30\%). Хоча у статтях, які вивчають якісні показники, дозволяється опущення таких складових емпіричного циклу, як перевірка однієї гіпотези, більшість дослідників все ж наполягає на гіпотетично-дедуктивному підході [2, 3].

Слід враховувати викладення матеріалу у статті під час його критичної оцінки. Як відомо, найлегшими для сприйняття є наукові статті 3 асоціативно-смисловим полем, що $є$ триступеневим: 1) вершина поля включає номінат концепту; 2) текстові смисли на другій сходинці; 3) це текстові асоціати, які галузяться на ще більш конкретні текстові асоціати [4]. Такий тип поля використовується нечасто у науковій літературі, оскільки містить суб'єктивне ставлення автора до описуваного ним явища та має на меті донести правильність власної думки до читача. Найчастіше таке викладення матеріалу спостерігається у санітарно-просвітницьких брошюрах, де цей вид поля допустимий та найкраще сприймається читачем. Недоліком його використання $€$ можливість керувати суспільною думкою, застосувавши емоційний фон у тих цілях, які вбачає автор.

Основним підручником для вироблення відмінних навичок ефективного пошуку та критичного оцінювання наукової медичної літератури $€$ "How to read a paper: the basics of evidence-based medicine” T. Greenhalgh. Книга перевидається 3 1996 р. вже у п’ятій редакції та перекладена на 10 мов, автор постійно удосконалює та додає нові аспекти роботи з літературою, що містить доказову базу та радить, як спростити прочитання та сприйняття громіздкої інформації. Наголошенням $€$ не лише вміння критично вичитати статтю, а також

\section{СПИСОК ЛІТЕРАТУРИ}

1. Gastel B. How to write and publish a scientific paper / B. Gastel, R. A. Day. - Santa Barbara, California: 8-th ed. Greenwood, 2016. - 326 p.

2. Greenhalgh T. How to read a paper: the basics of evidencebased medicine / T. Greenhalgh. - 5-th ed. Oxford: John Wiley \& Sons, Apr 2014. - 284p.

3. Boon M. Epistemology for interdisciplinary research shifting philosophical paradigms of science / M. Boon, S. Van здійснити пошук матеріалу за первинними потребами, тобто - правильно сформувати пошук та виокремити доказові дані, що $€$ найбільш обгрунтованими (за словами автора: “прочитання необхідної статті в необхідний час”). Саму ж критичну оцінку літератури Тріша Грінхальх разом з професором Девідом Саккетом виносять на третє місце [2]. Хоча не буде помилкою об'єднати в один пункт виявлення кращої доказової бази в опрацьованих статтях одночасно з критичною оцінкою матеріалів, оскільки це є процеси, які відбуваються практично синхронно, а в деяких випадках, оцінювання літератури передує обранню найоптимальнішого тексту.

Полегшує роботу з оглядом літератури початківцям також спеціально розроблені схеми з запитаннями, які акцентують увагу читача на зоровому емфазисі компонентів емпіричного циклу представленого наукового дослідження [5].

Вірне окреслення квінтесенції наукового повідомлення визначено у 71,25 \% респондентів, здатність виокреслити складові емпіричного циклу в обраних статтях - у 30 \% учасників, витрата продуктивного часу на матеріал, який опосередковано належить до пошукового запиту - у 7,5 \% студентів медичного факультету.

Перспективи подальших досліджень. Виробити навички ефективного керування інформаційними системами, які дозволяють звузити розмірність простору ознак до найбільш клінічно цінних (виокремити ті кількісні, якісні та номінальні ознаки патології, які необхідні для диференційної діагностики захворювань).

Baalen // European Journal for Philosophy of Science. - 2019. No. 9 (16).

4. Болотнова Н. С. Новое в изучении семантики и прагматики слова в художественном и публицистическом дискурсах / Н. С. Болотова, А. В. Курьянович // Сибирский филологический журнал. - 2009.-№ 1. - С. 226-230.

5. Wallas M. Critical reading and writing for postgraduates / M. Wallas, A. Wray. - London: 3-rd ed. SAGE, 2016. - 276 p.

4. Bolotnova, N.S., \& Kuryanovich, A.V. (2009). Novoe v izuchenii semantiki i pragmatiki slova $\mathrm{v}$ khudozhestvennom i publitsysticheskom diskursakh [The new in studying the semantics and pragmatics of the word in artistic and journalistic dicourses]. Sibirskiy filologicheskiy zhurnal - The Siberian Journal of Philology, 1, 226-230 [in Russian].

5. Wallas, M., \& Wray, A. (2016). Critical reading and writing for postgraduates. - London: 3-rd ed. SAGE.

Отримано 28.12.2018 
V. M. MATSKEVYCH, D. B. SOLOMCHAK

Ivano-Frankivsk National Medical University

\title{
A SELECTION OF RECEIVED SCIENTIFIC INFORMATION BY STUDENTS OF MEDICAL FACULTY FOR THE DESCRIPTION OF THE SEMANTIC FIELD OF THE MAIN REPRESENTED POSITIONS
}

The aim of the work: to determine the searching skills for literary sources with choice of information that has the best evidence base and the ability to distinguish a quintessence of a scientific message with the further development of analytical thinking by students of the natural sciences' faculties.

Materials and Methods. During the 2016-2018 years, 80 students of the medical faculty participated in the study, who had a topic for searching, processing and establishment of the most informative materials within the set time, determining the semantic field, critically evaluating the text and writing their own rating of the articles with evidence base. The number of processed articles, spending of productive time on the material, indirectly relates to the search query, the correctness of text quintessence, definition of empirical cycle components of scientific research.

Results and Discussion. During the set time, $42.5 \%$ of persons processed 10 or more articles, 51.25 \% - 5-9 articles, 6.25 \% - 1-4 articles. $7.5 \%$ of students took one third of the time to review information that was not related to a specific question. The quintessence of texts was done by 57 students (71.25 \%). 24 persons (30 \%) identified the empirical cycle components.

Key words: empirical cycle; search query; semantic field.

\section{СЕЛЕКЦИЯ ПОЛУЧЕННОЙ НАУЧНОЙ ИНФОРМАЦИИ СТУДЕНТАМИ МЕДИЦИНСКОГО ФАКУЛЬТЕТА ДЛЯ ОБОЗНАЧЕНИЯ СМЫС.ОВОГО ПОЛЯ ОСНОВНЫХ ПОДАННЫХ ПОЗИЦИЙ}

\begin{abstract}
Цель работы: определение навыков поиска литературных источников с выбором сведений, которые носят оптимальную доказательную базу и способности выделения квинтэссенции научного сообщения с последующим развитием аналитического мышления у студентов факультетов естественных наук.

Материалы и методы. В течение 2016-2018 гг. в исследовании участвовало 80 студентов медицинского факультета, которым дано тему для поиска и обработки с установлением наиболее информативных материалов в пределах установленного времени, определение семантического поля статьи, критической оценки текста и написании собственного рейтинга обработанных статей согласно наличия доказательной базы. Изучено количество прочитанных статей респондентами, расход продуктивного времени на материал, который косвенно относится к поисковому запросу, правильность выбора квинтэссенции текстов, определение компонентов эмпирического цикла научных исследований.

Результаты исследований и их обсуждение. В течение отведенного времени 42,5 \% анкетируемых лиц разработало 10 и более статей, 51,25 \% - 5-9 статей, 6,25 \% - 1-4 статьи. По заданным ключевым словам в поисковых запросах 7,5 \% студентов отвели около трети времени на рассмотрение информации, которая не связана с конкретным вопросом. С правильным выбором квинтэссенции текстов справилось 57 студентов (71,25 \%). Определили компоненты эмпирического цикла 24 человека (30 \%).
\end{abstract}

Ключевые слова: эмпирический цикл; поисковый запрос; семантическое поле. 